\title{
FAKTOR-FAKTOR KEINGINAN PINDAH AGEN REAL ESTATE WINSTON DI SURABAYA
}

\author{
Antonius Ricky Hartono ${ }^{1 *}$, Eddy Madiono Sutanto ${ }^{1}$ \\ ${ }^{1}$ Program Studi Manajemen, Universitas Kristen Petra \\ Jalan Siwalankerto 121-131, Surabaya 60236, Indonesia \\ * Penulis Korespondensi; E-mail: angelmoon_organizer@yahoo.com
}

\begin{abstract}
Abstrak
Penelitian ini bertujuan mengetahui faktor-faktor yang mempengaruhi keinginan pindah agen Real Estat Winston di Surabaya. Populasi dalam penelitian ini berjumlah 149 orang. Sampel penelitian menggunakan metode sampling insidental dengan tingkat kesalahan sebesar 10\%. Sampel penelitian sebanyak 113 orang. Penelitian ini menggunakan pendekatan kuantitatif. Teknik pengumpulan data menggunakan angket yang diisi oleh responden. Metode analisis data yang digunakan adalah analisis faktor. Analisis faktor diolah dengan menggunakan program Statistical Package for the Social Science (SPSS) yang terdiri dari dua tahap yaitu analisis deskriptif dan extraction. Hasil dari penelitian ini menunjukan bahwa faktor-faktor yang mempengaruhi keinginan pindah terdiri dari faktor individu dan faktor organisasi. Faktor individu lebih dominan daripada faktor organisasi.
\end{abstract}

Kata kunci: Keinginan pindah, faktor individu, faktor organisasi

\begin{abstract}
This research was conducted to determine the factors that affect the desire to move Winston real estate agent in Surabaya. The population in this study amounted to 149 people. The sample of this research used the method of sampling of incidental to the level of a $10 \%$ error. Sample of this research as many as 113 people. This research used a quantitative approach. The technique of collecting data used questionnaires completed by respondents. Methods of data analysis that was used by the analysis of the factor. Analysis of the factor was ordained by using program Statistical Package for the Social Science (SPSS) which consists of two stages: a descriptive analysis and extraction. The results of this research show that the factors which affect the desire to move were composed of factors of individual and organizational factors. Individual factors which are more dominant than the system factors of the organization.
\end{abstract}

\section{Keywords: Turnover intentions, individual factors, organizational factors}

\section{Pendahuluan}

Terjadinya hambatan dalam mendirikan suatu perusahaan ditentukan oleh faktor yang dapat memberikan keuntungan ataupun merugikan perusahaan. Salah satu faktor yang dapat membuat perusahaan mengalami perubahan adalah manusia. Ini dikarenakan manusia merupakan sumber daya yang dinamis dan selalu dibutuhkan dalam setiap proses produksi barang dan jasa. Manajemen perusahaan khususnya bidang manajemen sumber daya manusia dituntut untuk lebih memperhatikan kebijaksanaan terhadap pekerjanya. Kebijakan perusahaan yang tidak sesuai dengan kebutuhan dan harapan pekerja akan membawa dampak buruk pada sikap kerja pekerjanya. Terjadinya perpindahan pekerja (turnover) merupakan suatu hal yang tidak dikehendaki oleh perusahaan.

Turnover pekerja memang merupakan masalah klasik yang sudah dihadapi para pengusaha sejak era revolusi industri. Contohnya pergantian pekerja yang terus berjalan, baik pergantian pekerja karena faktor produktivitas pekerja yang menurun maupun pekerja yang mengundurkan diri (Gomes, 2003). Faktorfaktor yang mempengaruhi keinginan pindah pekerja bervariasi. Beberapa faktor yang mempengaruhi antara lain kepuasan kerja, usia, jenis kelamin, status pernikahan, pendidikan, dan masa kerja (Etnaningtiyas, 2011), kepuasan kerja dan stres kerja (Nayaputera, 2011), budaya organisasi, kepuasan kerja (Novliadi, 2007), hubungan kerja, kepemimpinan, partisipasi kerja, senioritas, jenis kelamin, working full time, burnout (Heinen et al., 2012), permintaan pekerjaan dan kepuasan kerja (Peterson, Hall, Pallas, \& Cockerill, 2011), kepuasan kerja (Alam \& Mohammad, 2010), kepuasan kerja dan komitmen organisasional (Sutanto \& Gunawan, 2013).

Real Estat merupakan salah satu lapangan pekerjaan yang memiliki peran untuk memajukan perekonomian Provinsi Jawa Timur. Hal ini digambarkan oleh Pendapatan Regional Regional Bruto (PDRB) provinsi Jawa Timur selalu mengalami peningkatan dari tahun ke tahun yang dapat dilihat pada Tabel 1. 
Tabel 1

PDRB Provinsi Jawa Timur Atas Dasar Harga Konstan Menurut Lapangan Usaha Tahun 2008-2012 (juta rupiah)

\begin{tabular}{lrrrrr}
\hline \multicolumn{1}{c}{ Lapangan Usaha } & \multicolumn{1}{c}{2008} & \multicolumn{1}{c}{2009} & \multicolumn{1}{c}{2010} & \multicolumn{1}{c}{2011} & 2012 \\
\hline Pertanian & $48.315 .111,68$ & $50.208 .896,71$ & $51.329 .548,83$ & $52.628 .433,15$ & $54.463 .942,77$ \\
Pertambangan dan Penggalian & $6.645 .089,71$ & $7.104 .816,81$ & $7.757 .319,82$ & $8.228 .632,48$ & $8.401 .262,86$ \\
Industri Pengolahan & $81.033 .880,59$ & $83.299 .893,42$ & $86.900 .779,13$ & $92.171 .191,46$ & $98.017 .056,47$ \\
Listrik, Gas, \& Air Bersih & $4.246 .146,61$ & $4.361 .515,81$ & $4.642 .081,81$ & $4.932 .084,36$ & $5.238 .431,69$ \\
Konstruksi & $9.887 .403,83$ & $10.307 .883,76$ & $10.992 .599,76$ & $11.994 .825,72$ & $12.840 .565,41$ \\
Perdagangan, Hotel \& Restauran & $90.911 .382,23$ & $95.983 .867,09$ & $106.229 .112,97$ & $116.645 .214,35$ & $128.375 .498,60$ \\
Pengangkutan \& Komunikasi & $20.164 .063,96$ & $22.781 .527,67$ & $25.076 .424,92$ & $27.945 .256,13$ & $30.640 .913,33$ \\
Keuangan, Real Estat, dan Jasa & $16.519 .146,41$ & $17.395 .393,53$ & $18.659 .490,17$ & $20.186 .109,19$ & $21.802 .468,45$ \\
Perusahaan & $27.816 .461,60$ & $29.417 .374,11$ & $30.693 .407,48$ & $32.251 .530,62$ & $33.886 .297,81$ \\
Jasa-jasa & $305.538 .686,62$ & $320.861 .168,91$ & $342.280 .764,89$ & $366.983 .277,46$ & $393.666 .437,37$ \\
\hline \multicolumn{1}{c}{ Total } & & & & &
\end{tabular}

Sumber: Badan Pusat Statistik, 2014

Surabaya sebagai Ibukota Provinsi Jawa Timur merupakan kota terbesar kedua di Indonesia setelah Jakarta. Fenomena tersebut turut menggambarkan bahwa sektor Real Estat merupakan sektor bisnis yang berkembang di Surabaya. Manajemen sumber daya manusia yang kurang baik dapat mempengaruhi pekerjanya. Hal ini didukung oleh data Tabel 2 yang berdasarkan wawancara dengan masing-masing staf kantor agen Real Estat Grup Winston kota Surabaya pada tanggal 20 Mei 2014.

\section{Tabel 2}

Tingkat Turnover Agen Real Estat di Perusahaan Agen Real Estat Grup Winston Kota Surabaya Selama Bulan Mei 2013-Mei 2014

\begin{tabular}{lccr}
\hline \multirow{2}{*}{ Nama Perusahaan Total Agen } & $\begin{array}{c}\text { Jumlah Agen } \\
\text { Keluar }\end{array}$ & Persen \\
\hline Winston Central & 43 & 18 & $41,86 \%$ \\
Winston Mitra & 19 & 7 & $36,84 \%$ \\
Winston One & 32 & 4 & $12,5 \%$ \\
Winston Premier & 28 & 9 & $32,14 \%$ \\
Winston Prima & 27 & 5 & $18,52 \%$ \\
\hline
\end{tabular}

Sebagai pemimpin perusahaan perlu mengetahui apa yang menyebabkan pekerja mereka keluar dari perusahaan. Menurut principal Winston Premier terdapat masalah yang biasa dialami oleh seorang agen Real Estat yaitu mereka tidak bisa survive dengan pekerjaannya, sehingga membuatnya menjadi depresi dan dapat menyebabkan mereka lebih memilih mengundurkan diri atau pindah pekerjaan lainnya.

Berdasarkan latar belakang masalah yang ada, maka rumusan masalah yang ada dalam penelitian ini adalah faktor-faktor apakah yang mempengaruhi keinginan pindah agen Real Estat Winston di Surabaya. Tujuan dari penelitian ini adalah mendeskripsi- kan dan menganalisis faktor-faktor apakah yang mempengaruhi keinginan pindah agen Real Estat Winston di Surabaya, serta untuk mengetahui faktor apakah yang dominan dalam mempengaruhi keinginan pindah agen Real Estat Winston di Surabaya.

Penelitian ini dibatasi hanya pada agen real estat yang pernah keluar atau masih menjadi bagian dari perusahaan agen Real Estat Grup Winston di Surabaya. Hal tersebut disebabkan karena kemudahan dalam mengakses data yang diperlukan dalam penelitian sehingga data lebih terpercaya. Batasan berikutnya adalah data perusahaan agen real estat grup Winston di Surabaya yang digunakan mulai bulan Mei 2013-Mei 2014, merupakan data terbaru dari perusahaan agen Real Estat Grup Winston di Surabaya.

\section{Keinginan Pindah Kerja}

Employee turnover mengarah pada kehilangan sejumlah pekerja yang dihadapi suatu perusahaan pada periode tertentu. Keinginan pindah kerja sendiri mengarah kepada hasil evaluasi individu mengenai kelanjutan hubungannya dengan sebuah perusahaan yang belum diwujudkan dalam tindakan nyata untuk meninggalkan perusahaan tersebut. Keinginan pindah kerja juga diartikan sebagai keinginan individu untuk meninggalkan organisasi dan mencari alternatif pekerjaan lain (Certo, 2000). Keinginan pindah kerja juga dapat diartikan sebagai penarikan diri secara sukarela atau tidak sukarela yang merupakan keputusan pekerja untuk meninggalkan perusahaan (Robbins \& Judge, 2013). Beberapa pengertian mengenai keinginan pindah kerja, memiliki kesamaan yaitu adanya keinginan pekerja untuk meninggalkan perusahaannya. 


\section{Faktor-Faktor Yang Mempengaruhi Keinginan Pindah Kerja}

Faktor-faktor yang mempengaruhi keinginan pindah kerja cukup kompleks dan saling berkaitan satu sama lain. Faktor-faktor yang akan dibahas antara lain adalah usia, masa kerja, tingkat pendidikan, jenis kelamin, status pernikahan, komitmen organisasi, budaya organisasi, kepuasan kerja, stres kerja, dan partisipasi kerja (Etnaningtiyas, 2011; Sutanto \& Gunawan, 2013; Novliadi, 2007; Mangkunegara, 2013).

Usia merupakan suatu tahapan perkembangan individu yang mengalami pertumbuhan dan perkembangan sangat potensial. Pekerja yang berusia muda memiliki tingkat turnover yang lebih tinggi daripada pekerja yang lebih tua. Pekerja yang berusia tua memiliki tingkat turnover lebih rendah karena memiliki tanggung jawab terhadap keluarga, mobilitas yang menurun, tidak mau susah untuk berpindah-pindah pekerjaan dan memulai pekerjaan dari awal lagi di tempat kerja yang baru serta senioritas belum tentu diperoleh di tempat kerja yang baru walaupun gaji dan fasilitasnya lebih besar (Robbins \& Judge, 2013).

Masa kerja adalah jangka waktu orang yang sudah bekerja pada suatu perusahaan (Robbins \& Judge, 2013). Menurut Desa (2008), menyatakan bahwa pekerja yang memiliki masa kerja $\leq 3$ tahun lebih sering melakukan turnover karena masa kerja yang singkat memiliki keinginan untuk mencari sebuah tantangan baru dalam pekerjaannya.

Pekerja yang memiliki pendidikan D-3 lebih banyak pindah dari perusahaan dibandingkan dengan pekerja yang memiliki pendidikan S-1. Hal ini dikarenakan pekerja yang memiliki pendidikan lebih rendah berharap mendapatkan pekerjaan yang lebih baik daripada pekerjaan sebelumnya serta perlakuan yang setara dengan pekerja yang berpendidikan lebih tinggi (Andini, 2006).

Jenis kelamin adalah kelompok yang terbentuk dalam suatu spesies sebagai sarana atau akibat digunakannya proses reproduksi seksual untuk mempertahankan keberlangsungan spesiesnya. Jenis kelamin pada manusia berkaitan dengan laki-laki ataupun perempuan. Kaum wanita memiliki tingkat turnover yang lebih tinggi daripada kaum pria, kaum wanita yang dimaksud adalah wanita yang sudah menikah wanita tersebut memiliki dua peran dan tanggung jawab yang besar, baik sebagai ibu rumah tangga maupun wanita karir (Robbins \& Judge, 2013).

Status pernikahan adalah status seseorang yang menyatakan bahwa sudah menikah atau belum menikah. Pekerja yang sudah menikah memiliki tingkat absen lebih rendah daripada pekerja yang belum menikah sehingga dapat disimpulkan bahwa pekerja yang sudah menikah memiliki tingkat turnover lebih rendah dan merasa lebih puas dengan pekerjaan yang dimilikinya (Robbins \& Judge, 2013).

Menurut Robbins and Judge (2013) komitmen organisasional merupakan suatu keadaan pekerja memihak kepada perusahaan tertentu dengan tujuantujuannya serta ingin memelihara keanggotaannya dalam perusahaan tersebut. Komitmen organisasional juga berkaitan dengan keinginan yang tinggi seorang pekerja untuk berbagi dan berkorban bagi perusahaan. Menurut Sutapa (2003), bahwa komitmen organisasional adalah keadaan seorang pekerja memihak kepada suatu perusahaan tertentu dan tujuan-tujuannya, serta berniat memelihara keanggotaannya dalam perusahaan tersebut.

Menurut Kast (1990) bahwa budaya organisasi adalah sistem nilai dan kepercayaan yang dianut bersama, berinteraksi dengan orang-orang dalam suatu organisasi, struktur organisasi dan sistem pengawasan untuk menghasilkan norma-norma perilaku. Budaya organisasi yang kuat memiliki pengaruh yang cukup besar pada perilaku pekerja dan secara langsung mengurangi tingkat turnover. Dalam budaya yang kuat, nilai-nilai utama sebuah organisasi sangat dipegang teguh dan tertanam pada seluruh pekerjanya. Semakin banyak pekerja yang menerima nilainilai tersebut dan semakin besar komitmen terhadapnya, maka semakin kuat budaya organisasinya. Budaya yang kuat ini akan membentuk kesetiaan dan komitmen pekerja terhadap organisasi yang akan mengurangi keinginan pekerja untuk meninggalkan organisasi (Robbins \& Judge, 2013).

Kepuasan kerja adalah perasaan menyokong atau tidak menyokong yang dialami pekerja dalam bekerja. Pekerja akan merasa puas dalam bekerja apabila aspek-aspek pekerjaan dan aspek-aspek tertentu menyokong dirinya dan sebaliknya jika aspek-aspek tersebut tidak menyokong dirinya maka pekerja akan merasa tidak puas. Kepuasan kerja tinggi dihubungkan dengan tingkat turnover pekerja yang rendah, sedangkan pekerja yang kurang puas biasanya memiliki tingkat turnover lebih tinggi (Mangkunegara, 2013). Perasaan tidak puas juga dapat menimbulkan pikiran pekerja untuk keluar dari perusahaan dengan cara mencari pekerjaan yang lainnya (Mobley, 1986).

Stres kerja adalah perasaan tertekan yang dialami pekerja dalam menghadapi pekerjaan. Penyebab stres kerja antara lain beban kerja yang dirasakan terlalu berat, waktu kerja yang mendesak, kualitas pengawasan kerja yang rendah, iklim kerja yang tidak sehat, otoritas kerja yang tidak memadai serta ber- 
hubungan dengan tanggung jawab, konflik kerja, perbedaan nilai antara pekerja dengan pemimpin yang frustasi dalam kerja (Mangkunegara, 2013). Stres kerja yang tidak mampu diatasi pekerja dapat mempengaruhi kinerja pekerja. Hal tersebut membuat pekerja kehilangan semangat dalam bekerja sehingga dapat menimbulkan keinginan untuk pindah kerja. Apabila pekerja mampu mengatasi stres kerja, maka kinerja pekerja akan tetap bertahan. Para pekerja juga dapat bekerja sama dengan pekerja lainnya secara maksimal sehingga pekerjaan lebih cepat, tingkat absensi dapat diperkecil, serta keinginan untuk pindah kerja dapat diperkecil (Agustina, 2013).

Partisipasi adalah keterlibatan emosi dan mental pekerja dalam situasi kelompok yang menggiatkan mereka untuk menyumbang pada tujuan kelompok serta bertanggung jawab terhadap hal tersebut (Mangkunegara, 2013). Berdasarkan definisi tersebut, terdapat tiga aspek yang sangat penting sehingga dapat melihat pekerja dalam partisipasi kerjanya yaitu keterlibatan emosi dan mental pekerja, motivasi untuk menyumbang (kontribusi), dan penerimaan tanggung jawab.

\section{Metode Penelitian}

Penelitian ini merupakan penelitian deskriptif dengan metode penelitian pendekatan kuantitatif. Penelitian deskriptif bertujuan menggambarkan secara sistematik dan akurat fakta dan karakteristik mengenai populasi atau mengenai bidang tertentu. Hal ini karena data yang dikumpulkan semata-mata bersifat deskriptif sehingga tidak bermaksud mencari penjelasan, menguji hipotesis, membuat prediksi, maupun mempelajari implikasi (Azwar, 2005). Penelitian ini mendeskripsikan tentang faktor-faktor yang mempengaruhi keinginan pindah agen real estat Winston di Surabaya.

Populasi adalah wilayah generalisasi yang terdiri atas objek atau subjek yang mempunyai kualitas dan karakteristik tertentu yang ditetapkan untuk dipelajari kemudian ditarik kesimpulannya (Sugiyono, 2010). Populasi dalam penelitian ini adalah agen Real Estat Winston di Surabaya. Berdasarkan data perusahaan terdapat 149 orang yang menjadi agen real estat Winston di Surabaya.

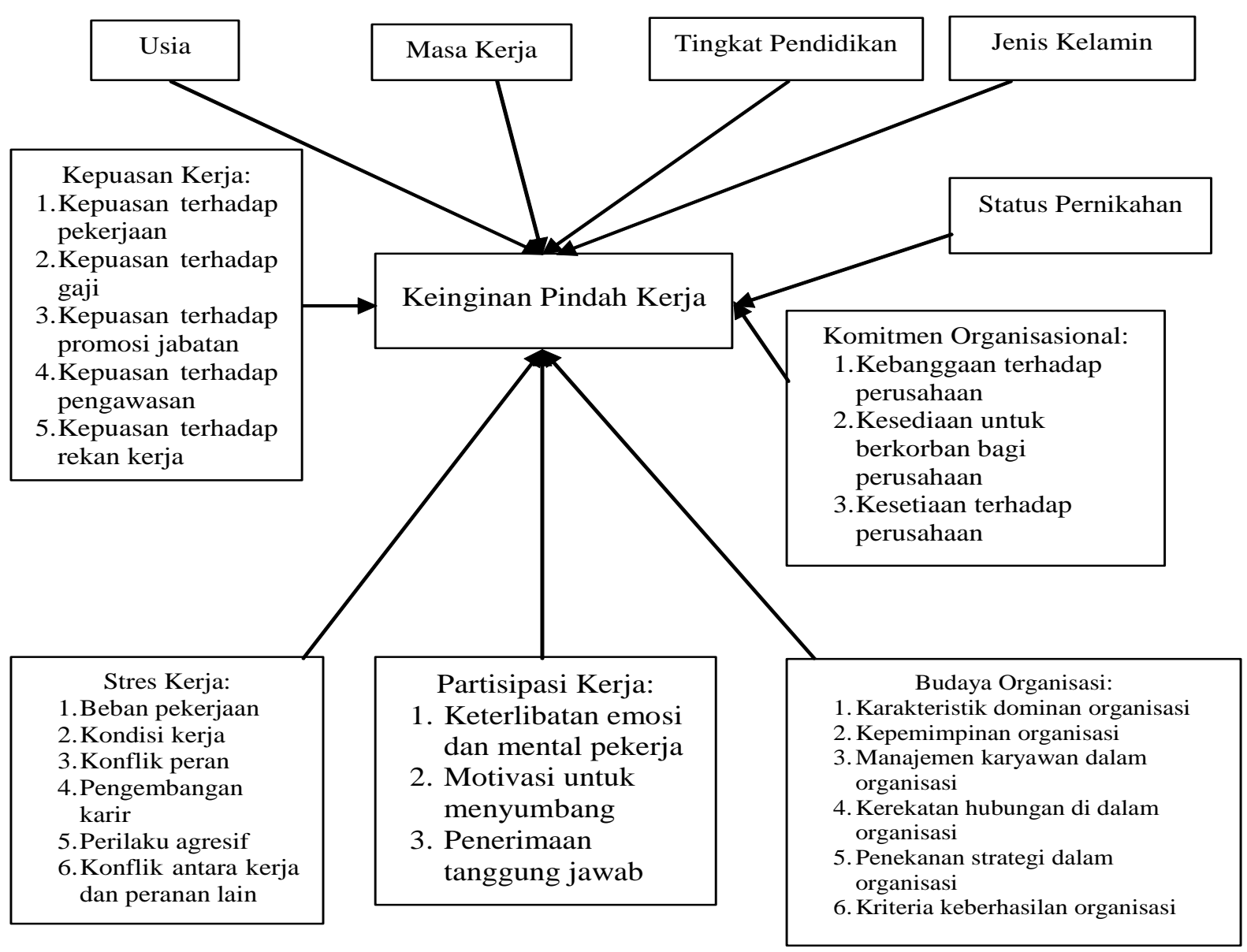

Gambar 1. Kerangka berpikir

Sumber: Hellriegel and Slocum, 2011; Ivancevich, Konopaske, and Matteson, 2012; Robbins and Judge, 2013; Sutanto dan Gunawan, 2013; Mangkunegara, 2013 
Sampel adalah bagian dari jumlah dan karakteristik yang dimiliki oleh populasi (Sugiyono, 2010). Teknik pengambilan sampel yang digunakan dalam penelitian ini termasuk non probability sampling. Non probability sampling adalah teknik pengambilan sampel yang tidak memberikan peluang atau kesempatan sama bagi setiap unsur atau anggota populasi untuk dipilih menjadi sampel (Sugiyono, 2010). Teknik pengambilan sampel yang digunakan adalah sampling insidental. Sampling insidental adalah teknik penentuan sampel berdasarkan kebetulan, yaitu siapa saja yang secara kebetulan bertemu dengan peneliti dapat digunakan sebagai sampel apabila orang yang ditemui tersebut cocok sebagai sumber data (Sugiyono, 2010). Sampel dalam penelitian ini dibagi menjadi dua kelompok yaitu pertama agen Real Estat yang masih menjadi bagian perusahaan agen Real Estat grup Winston di Surabaya berjumlah 106 orang. Kedua agen Real Estat yang pernah keluar dari perusahaan agen real estat grup Winston di Surabaya berjumlah 43 orang. Tingkat kesalahan untuk jumlah sampel penelitian ini sebesar 10\% sehingga jumlah sampel menjadi 78 orang dan 35 orang (Sugiyono, 2010).

\section{Definisi Operasional}

Definisi mengenai variabel yang dirumuskan berdasarkan karakteristik-karakteristik variabel tersebut yang dapat diamati (Azwar, 2005). Definisi operasional dari variabel yang digunakan dalam penelitian ini adalah sebagai berikut:

Pertama, usia merupakan tahapan perkembangan individu yang mengalami pertumbuhan potensial. Kedua, masa kerja merupakan jangka waktu orang yang sudah bekerja pada suatu perusahaan. Ketiga, tingkat pendidikan merupakan proses perubahan sikap dan tingkah laku seseorang melalui pengajaran dan pelatihan. Keempat, jenis kelamin merupakan kelompok yang terbentuk dalam suatu spesies akibat digunakannya proses reproduksi seksual untuk mempertahankan keberlangsungan spesiesnya. Kelima, status pernikahan merupakan status seseorang yang menyatakan bahwa sudah menikah atau belum menikah. Keenam, komitmen organisasional merupakan keinginan yang tinggi seorang pekerja untuk berbagi dan berkorban bagi perusahaan. Ada tiga indikator untuk mengukur tinggi rendahnya komitmen organisasional, yaitu kebanggaan terhadap perusahaan, kesediaan untuk berkorban bagi perusahaan, dan kesetiaan terhadap perusahaan. Ketujuh, budaya organisasi merupakan sistem nilai dan kepercayaan yang dianut bersama untuk menghasilkan normanorma perilaku. Ada enam indikator untuk mengukur tinggi rendahnya budaya organisasi, yaitu karakteristik dominan organisasi, kepemimpinan organisasi, manajemen pekerja dalam organisasi, kerekatan hubungan di dalam organisasi, penekanan strategi dalam organisasi, kriteria keberhasilan organisasi. Kedelapan, kepuasan kerja merupakan suatu perasaan yang menyokong atau tidak menyokong diri pekerja yang berhubungan dengan pekerjaannya. Ada lima indikator untuk mengukur tinggi rendahnya kepuasan kerja, yaitu kepuasan terhadap pekerjaan, kepuasan terhadap gaji, kepuasan terhadap promosi jabatan, kepuasan terhadap pengawasan, kepuasan terhadap rekan kerja. Kesembilan, stres kerja merupakan perasaan tertekan yang dialami pekerja dalam menghadapi pekerjaan. Ada enam indikator untuk mengukur tinggi-rendahnya stres kerja, yaitu beban pekerjaan, kondisi kerja, konflik peran, pengembangan karir, perilaku agresif, konflik antara kerja dan peranan lain. Kesepuluh, partisipasi kerja merupakan keterlibatan emosi dan mental pekerja dalam menyumbang untuk tujuan kelompok. Ada tiga indikator untuk mengukur tinggi-rendahnya partisipasi kerja, yaitu keterlibatan emosi dan mental pekerja, memiliki keinginan untuk berkontribusi dalam bekerja, dan penerimaan tanggung jawab.

Metode pengumpulan data melalui angket. Angket merupakan teknik pengumpulan data yang dilakukan dengan cara memberi seperangkat pertanyaan atau pernyataan tertulis kepada responden untuk dijawab (Sugiyono, 2010). Angket menggunakan tipe pertanyaan tertutup dan bentuknya menggunakan kalimat positif dan negatif. Responden dalam penelitian ini adalah agen Real Estat yang pernah keluar atau masih menjadi bagian perusahaan agen Real Estat Grup Winston di Surabaya. Ada pun penelitian ini menggunakan skala likert dalam menjawab pertanyaan-pertanyaan pada angket. Skala likert merupakan suatu alat ukur yang digunakan dalam penelitian untuk memperoleh data interval (Cooper \& Schindler, 2008). Skala likert yang digunakan adalah skala 5 dengan kategori.

\section{Metode Analisis Data}

\section{Uji Validitas}

Menurut Sugiyono (2010) menyatakan uji validitas digunakan untuk mengukur sah atau valid tidaknya suatu angket. Angket dikatakan valid jika pertanyaan angket mampu untuk mengungkapkan sesuatu yang akan diukur oleh angket tersebut. Uji validitas ini dapat dilakukan dengan cara menghitung korelasi item-item pernyataan dengan total item pernyataan dengan menggunakan program Statistical 
Package for the Social Science (SPSS). Pengujian validitas dilakukan dengan cara melihat tingkat korelasi antara masing-masing pernyataan dalam satu variabel dengan nilai total variabel (Corrected ItemTotal Correlation) dari program SPSS. Dasar pengambilan keputusan yatu jika $r_{\text {hitung }}$ positif, serta $r_{\text {hitung }}>$ $r_{\text {tabel }}$, maka butir atau variabel tersebut valid atau jika $r_{\text {hitung }}$ tidak positif, serta $r_{\text {hitung }}<r_{\text {tabel }}$, maka butir atau variabel tersebut tidak valid.

\section{Uji Reliabilitas}

Ghozali (2005) menyatakan reliabilitas adalah alat untuk mengukur suatu angket yang merupakan indikator dari variabel. Suatu angket dikatakan reliabel atau handal jika jawaban seorang terhadap pertanyaan adalah konsisten atau stabil dari waktu ke waktu. Cara untuk mengetahui sejauh mana reliabilitas angket dalam penelitian ini digunakan pendekatan konsistensi internal dengan menghitung koefisien Cronbach's Alpha, yang diolah dengan menggunakan program Statistical Package for the Social Science (SPSS). Menurut Ghozali (2005), instrumen dikatakan reliabel jika koefisien Cronbach's Alpha lebih dari 0,6 .

\section{Analisis Faktor}

Analisis faktor ini dapat diolah dengan menggunakan program Statistical Package for the Social Science (SPSS). Pertama, analisis deskriptif yang memberikan gambaran tentang data yang dimiliki. Dalam analisis faktor, gambaran diberikan melalui mean (perhitungan rata-rata) dan standar deviasi setiap variabel. Dalam analisis deskriptif dilakukan tiga macam tes, yaitu 1) KMO and Barlett's Test. Kaiser Meyer Olkin Measure of Sampling Adequacy (KMO) merupakan sebuah indeks perbandingan jarak antara koefisien korelasi dengan koefisien korelasi parsialnya. Angka yang dihasilkan oleh $K M O$ harus lebih besar dari 0,5 agar analisis faktor dapat diproses lebih lanjut. 2) Barlett's Test of Sphericity merupakan tes yang digunakan untuk menguji ketergantungan antara variabel-variabel yang menjadi indikator suatu faktor. Analisis ini bertujuan untuk menyatakan bahwa variabel-variabel yang dimaksud tidak berkorelasi satu dengan lainnya dalam populasi. Angka signifikan dalam tes ini harus menunjukkan angka signifikan lebih kecil dari 0,05 agar analisis faktor dapat dilakukan. 3) Anti Image Matrices. Tabel anti image matrices digunakan untuk melihat variabel-variabel mana saja yang layak untuk dibuat analisis faktor sedangkan angka-angka dalam matriks menyatakan korelasi parsial antar variabel yaitu korelasi yang tidak dipengaruhi oleh variabel lain. Seluruh nilai Measures of Sampling Adequacy (MSA) yang memiliki notasi $\left({ }^{a}\right)$ harus lebih besar atau sama dengan 0,5 agar analisis faktor dapat diproses lebih lanjut.

Kedua, extraction merupakan metode untuk mereduksi data dari beberapa variabel menjadi beberapa faktor yang lebih sedikit. Melalui metode ini akan diperoleh hasil yakni 1). Communalities. Communalities adalah jumlah kuadrat masing-masing factor loading sebuah variabel yang digunakan untuk menunjukkan proporsi variabel penelitian secara parsial terhadap faktor-faktor yang diekstrak secara stimulant. Nilai standar minimum adalah korelasi masing-masing variabel secara parsial dengan dirinya sendiri. Communalities ini menyatakan varians setiap variabel yang dijelaskan dalam faktor dan angka yang terdapat pada kolom communalities tersebut selalu bernilai positif. Semakin besar nilai communalities, menunjukkan semakin kuat hubungan dengan faktor yang nantinya akan terbentuk.

Kedua adalah Total Variance Explained. Total variance explained berfungsi untuk mengekstrak sejumlah variabel menjadi beberapa faktor baru. Setiap faktor dalam total variance explained mewakili variabel-variabel yang dianalisis, ditunjukkan oleh besarnya varians yang dijelaskan. Varians yang dimaksud adalah varians variabel-variabel yang sudah distandariasi. Tabel total variance explained terdapat extraction sums of square loadings didasarkan pada eigenvalue yang lebih besar atau sama dengan 1. Jumlah faktor yang diekstrasi dalam pendekatan ini didasarkan pada persentase variasi kumulatif, faktor-faktor yang diekstrasi mencapai kurang lebih $60 \%$ dari variasi.

Ketiga adalah Component Matrix dan Rotated Component Matrix. Kedua tabel ini berguna untuk menjelaskan distribusi variabel-variabel ke dalam faktor-faktor yang terbentuk. Component matrix memuat koefisien yang digunakan untuk menyatakan variabel standar yang disebut faktor. Koefisien factor loading menerangkan korelasi antara variabel asal dengan faktornya. Nilai korelasi yang besar menyatakan hubungan yang erat antara faktor variabel asal sehingga variabel dapat digunakan untuk membentuk faktor. Dalam suatu matriks yang kompleks, sangat sulit menginterpretasikan faktor. Oleh karena itu, penggunaan rotasi faktor untuk mempermudah interpretasi dalam menentukan variabel-variabel mana saja yang tercantum atau masuk dalam suatu faktor dengan bentuk lebih sederhana. Penelitian ini menggunakan metode rotasi varmax method, yaitu rotasi yang bertujuan untuk meminimalkan jumlah variabel yang mempunyai factor loading tinggi pada setiap 
faktor. Variabel yang memiliki factor loading lebih kecil dari 0,4 dianggap memiliki kontribusi yang lemah terhadap faktor yang terbentuk sehingga harus dikeluarkan dari faktor yang dibentuknya. Nilai eigenvalue yang terbesar diantara faktor lain dapat menenentukan faktor mana yang paling dominan.

\section{Hasil Penelitian dan Pembahasan}

Tabel 3

Hasil Uji Validitas

\begin{tabular}{cccc}
\hline Indikator & $r_{\text {hitung }}$ & $r_{\text {tabel }}$ & Keterangan \\
\hline Usia & 0,649 & 0,185 & Valid \\
MK & 0,714 & 0,185 & Valid \\
TP & 0,616 & 0,185 & Valid \\
JK & 0,701 & 0,185 & Valid \\
SM & 0,680 & 0,185 & Valid \\
KO1 & 0,904 & 0,185 & Valid \\
KO2 & 0,699 & 0,185 & Valid \\
KO3 & 0,920 & 0,185 & Valid \\
BO1 & 0,750 & 0,185 & Valid \\
BO2 & 0,785 & 0,185 & Valid \\
BO3 & 0,691 & 0,185 & Valid \\
BO4 & 0,745 & 0,185 & Valid \\
BO5 & 0,688 & 0,185 & Valid \\
BO6 & 0,681 & 0,185 & Valid \\
KK1 & 0,683 & 0,185 & Valid \\
KK2 & 0,733 & 0,185 & Valid \\
KK3 & 0,628 & 0,185 & Valid \\
KK4 & 0,718 & 0,185 & Valid \\
KK5 & 0,691 & 0,185 & Valid \\
SK1 & 0,808 & 0,185 & Valid \\
SK2 & 0,834 & 0,185 & Valid \\
SK3 & 0,819 & 0,185 & Valid \\
SK4 & 0,849 & 0,185 & Valid \\
SK5 & 0,605 & 0,185 & Valid \\
SK6 & 0,643 & 0,185 & Valid \\
PK1 & 0,653 & 0,185 & Valid \\
PK2 & 0,932 & 0,185 & Valid \\
PK3 & 0,932 & 0,185 & Valid \\
\hline & & &
\end{tabular}

Berdasarkan Tabel 3, dapat dilihat bahwa nilai korelasi pearson $\left(r_{\text {hitung }}\right)$ dari setiap pernyataan lebih besar dari nilai $r_{\text {tabel }}(0,185)$. Kesimpulannya adalah semua item pernyataan yang digunakan dalam angket adalah valid dan bisa digunakan dalam penelitian ini.

Berdasarkan Tabel 4, dapat dilihat bahwa nilai Cronbach Alpha yang diperoleh adalah 0,945 lebih besar dari nilai kritis yaitu 0,6. Kesimpulannya semua pernyataan yang digunakan dalam angket penelitian ini bersifat reliabel.

Tabel 4

Hasil Uji Reliabilitas

\begin{tabular}{ccc}
\hline Cronbach's Alpha & Nilai Kritis & Keterangan \\
\hline 0,945 & 0,6 & Reliabel \\
\hline
\end{tabular}

Analisis Faktor

\section{KMO dan Bartlett's Test}

Tabel 5

KMO dan Bartlett's Test

\begin{tabular}{cc}
\hline KMO & Bartlett's Test \\
\hline \multirow{2}{*}{$M S A=0,845$} & Chi Square $=812,121$ \\
& Sig. $=0,000$ \\
\hline
\end{tabular}

Tabel 5 menunjukkan bahwa nilai MSA sebesar $0,845>0,5$, sehingga variabel-variabel yang digunakan dalam penelitian ini bisa diprediksi dan bisa dianalisis lebih lanjut. Tabel 5 juga menunjukkan Bartlett's Test menghasilkan nilai signifikansi sebesar $0,000<0,05(\alpha=5 \%)$, sehingga variabel-variabel yang digunakan tidak saling berkorelasi dan sesuai untuk digunakan analisis faktor.

\section{Anti Image Matrices}

Tabel 6

Anti Image Matrices

\begin{tabular}{cc}
\hline Indikator & $M S A$ \\
\hline Usia & 0,942 \\
MK & 0,949 \\
TP & 0,893 \\
JK & 0,913 \\
SM & 0,788 \\
KO & 0,656 \\
BO & 0,662 \\
KK & 0,925 \\
SK & 0,800 \\
PK & 0,886 \\
\hline
\end{tabular}

Berdasarkan Tabel 6 dapat dilihat bahwa seluruh nilai Measures of Sampling Adequacy (MSA) untuk seluruh faktor-faktor yang mempengaruhi keinginan pindah agen Real Estat Winston di Surabaya memiliki notasi $\left({ }^{a}\right)$ lebih besar dari 0,5 . Hal ini berarti bahwa analisis faktor dapat diproses lebih lanjut.

\section{Communalities}

Tabel 7

Communalities

\begin{tabular}{ccc}
\hline Indikator & Initial & Extraction \\
\hline Usia & 1,000 & 0,573 \\
MK & 1,000 & 0,660 \\
TP & 1,000 & 0,536 \\
JK & 1,000 & 0,659 \\
SM & 1,000 & 0,690 \\
KO & 1,000 & 0,895 \\
BO & 1,000 & 0,905 \\
KK & 1,000 & 0,400 \\
SK & 1,000 & 0,866 \\
PK & 1,000 & 0,828 \\
\hline
\end{tabular}


Berdasarkan Tabel 7 dapat dilihat ekstraksi masing-masing variabel, nilai ekstraksi menunjukkan kontribusi masing-masing variabel penelitian terhadap dua faktor yang diekstrak. Contohnya nilai ekstraksi dari variabel usia sebesar 0,573 atau $57,3 \%$ yang artinya variabel usia memberikan kontribusi sebesar $57,3 \%$ terhadap subfaktor baru yang terbentuk. Nilai ektraksi tertinggi dari variabel-variabel yang ada adalah 0,905 atau $90,5 \%$ dan yang terendah adalah 0,400 atau $40 \%$.

\section{Total Variance Explained}

Tabel 8

Total Variance Explained

\begin{tabular}{|c|c|c|c|}
\hline \multirow{2}{*}{ Component } & \multicolumn{3}{|c|}{ Initial Eigenvalues } \\
\hline & Total & $\%$ of Variance & Cumulative \% \\
\hline 1 & 5,490 & 54,897 & 54,897 \\
\hline 2 & 1,522 & 15,217 & 70,113 \\
\hline 3 & 0,757 & 7,568 & 77,681 \\
\hline 4 & 0,609 & 6,091 & 83,772 \\
\hline 5 & 0,448 & 4,479 & 88,251 \\
\hline 6 & 0,424 & 4,240 & 92,491 \\
\hline 7 & 0,307 & 3,068 & 95,559 \\
\hline 8 & 0,213 & 2,126 & 97,685 \\
\hline 9 & 0,162 & 1,622 & 99,307 \\
\hline 10 & 0,069 & 0,693 & 100,000 \\
\hline
\end{tabular}

Berdasarkan Tabel 8 , faktor yang mempunyai nilai eigenvalues lebih besar dari 1 adalah sebanyak dua faktor, kedua faktor tersebut dapat menjelaskan $70,113 \%$ keragaman variabel asal.

\section{Component Matrix}

Tabel 9

Component Matrixa

\begin{tabular}{ccc}
\hline & \multicolumn{2}{c}{ Component } \\
\cline { 2 - 3 } & 1 & 2 \\
\hline SK & 0,909 & $-0,200$ \\
PK & 0,897 & $-0,152$ \\
MK & 0,812 & 0,040 \\
JK & 0,808 & $-0,072$ \\
SM & 0,789 & $-0,261$ \\
Usia & 0,734 & $-0,184$ \\
TP & 0,731 & $-0,032$ \\
KK & 0,619 & $-0,130$ \\
KO & 0,475 & 0,818 \\
BO & 0,491 & 0,814 \\
\hline
\end{tabular}

Terdapat dua faktor baru yang terbentuk, maka langkah selanjutnya adalah mengetahui kelayakan suatu indikator masuk dalam faktor baru. Menentukan variabel mana yang akan masuk ke dalam suatu faktor dapat dilihat dari nilai loading factor (komponen matriks) yang terbesar. Tabel 9 menghasilkan kesimpulan yaitu faktor 1 yang terdiri dari stres kerja, partisipasi kerja, masa kerja, jenis kelamin, status pernikahan, usia, tingkat pendidikan, dan kepuasan kerja. Faktor 2 terdiri dari komitmen organisasional dan budaya organisasi.

Faktor 1 dan faktor 2 yang terbentuk diberi nama sesuai dengan isi dari setiap faktor. Pemberian nama untuk faktor baru yang terbentuk tidak memiliki aturan khusus sehingga pemberian nama terhadap dua faktor baru yang terbentuk yaitu faktor 1 disebut faktor individu, sedangkan faktor 2 disebut faktor organisasi.

Hasil analisis data tersebut memberi informasi bahwa faktor-faktor yang mempengaruhi keinginan pindah agen Real Estat Winston di Surabaya terdiri dari stres kerja, partisipasi kerja, masa kerja, jenis kelamin, status pernikahan, usia, tingkat pendidikan, kepuasan kerja, komitmen organisasional dan budaya organisasi. Faktor-faktor tersebut membentuk dua faktor baru yang diberi nama faktor individu dan faktor organisasi. Dua faktor baru yang terbentuk terdapat satu faktor yang dominan yaitu faktor individu. Total variance faktor individu lebih besar daripada nilai total variance faktor organisasi yang dapat dilihat pada Tabel 8 .

Dominasi faktor individu lebih besar daripada faktor organisasi sebagai faktor penyebab keinginan pindah agen Real Estat Winston di Surabaya. Hal ini dikarenakan oleh sifat masing-masing individu yang cenderung berambisi untuk meraih komisi sebesarbesarnya (Agustina, 2013), memiliki sifat egois atau individual dibandingkan bekerja secara tim (Mangkunegara, 2013), senioritas yang ada di dalam perusahaan (Desa, 2008; Robbins \& Judge, 2013), diskriminasi gender, kebutuhan keluarga yang tinggi, pola pikir seseorang, dan keterbatasan pengetahuan seseorang (Robbins \& Judge, 2013), tidak mudah puas terhadap hasil kerja (Mangkunegara, 2013).

Hasil analisis data tersebut juga dapat memberi informasi bagi perusahaan dalam menentukan kebijakan yang tepat untuk sumber daya manusia, seperti misalnya penghargaan kepada pekerja yang berprestasi, budaya perusahaan yang membangun karakter pekerja, dan lain-lain. Hal ini dapat memperkecil keinginan pindah pekerjanya dan dapat meningkatkan kinerja perusahaan. Penelitian ini memiliki faktor-faktor keinginan pindah pekerja lebih bervariasi daripada penelitian lainnya. Etnaningtiyas (2011) yang meneliti faktor-faktor keinginan pindah pada pekerja PT Alenatex Bandung memiliki hasil 
penelitian yakni kepuasan kerja, usia, jenis kelamin, status pernikahan, pendidikan, dan masa kerja merupakan faktor-faktor yang mempengaruhi keinginan pindah pekerja. Nayaputera (2011) membuktikan bahwa kepuasan kerja dan stres kerja mampu mempengaruhi keinginan pindah pekerja PT Plaza Indonesia Realty Tbk. Novliadi (2007) membuktikan bahwa hubungan antara budaya organisasi dan kepuasan kerja dengan keinginan pindah bersifat negatif. Artinya semakin tinggi tingkat kepuasan kerja dan semakin kuat budaya organisasi, maka semakin rendah tingkat keinginan pindah pekerja.

\section{Simpulan dan Implikasi}

Berdasarkan pembahasan di atas, maka dapat diambil beberapa kesimpulan. Pertama, faktor-faktor yang mempengaruhi keinginan pindah agen real estat terdiri dari sepuluh faktor yang membentuk dua faktor baru yaitu faktor individu. Faktor individu, yang terdiri dari stres kerja, partisipasi kerja, masa kerja, jenis kelamin, status pernikahan, usia, tingkat pendidikan, dan kepuasan kerja. Faktor kedua adalah faktor organisasi, yang terdiri dari komitmen organisasional dan budaya organisasi. Kedua, pengelompokan nama yang terdiri dari faktor individu dan faktor organisasi dapat mewakili 70,113\% dari sepuluh faktor awal. Ketiga, faktor individu yang terdiri dari stres kerja, partisipasi kerja, masa kerja, jenis kelamin, status pernikahan, usia, tingkat pendidikan, dan kepuasan kerja merupakan faktor yang dominan untuk mempengaruhi keinginan pindah agen real estat Winston di Surabaya.

Saran yang dapat diberikan adalah perusahaan sebaiknya memperhatikan hubungan antar pekerja agar hubungan yang dibentuk dapat lebih kompak lagi. Ini dikarenakan hubungan kerjasama yang kompak dapat membentuk lingkungan kerja yang nyaman dan hasil kerja bisa lebih maksimal. Perusahaan sebaiknya memberikan penghargaan kepada pekerja yang menunjukkan prestasi yang baik, karena pekerja tersebut sudah bersedia berkorban dan berjuang untuk perusahaan. Bagi penelitian selanjutnya disarankan agar dapat memperluas subjek penelitian di perusahaan agen real estat lainnya. Ini agar dapat memberikan informasi yang lebih luas kepada pembaca yang tertarik dengan dunia agen Real Estat.

\section{Daftar Referensi}

Agustina, N. A. (2013). Pengaruh stres kerja terhadap turnover pekerja bagian produksi PT Longvin Indonesia Sukabumi Jawa Barat. Unpublished undergraduate thesis, Institut Pertanian Bogor University, Jawa Barat, Indonesia.
Alam, M. M., \& Mohammad, J. F. (2010). Level of job satisfaction and intent to leave among Malaysian nurses. Business Intelligence Journal 3 (1), 2010, 123-137.

Andini, R. (2006). Analisis pengaruh kepuasan gaji, kepuasan kerja, komitmen organisasional terhadap turnover intention. Unpublished undergraduate thesis, Diponegoro University, Semarang Indonesia.

Azwar, S. (2005). Metode penelitian. Yogyakarta: Pustaka Pelajar.

Badan Pusat Statistik. (2014). PDRB atas dasar harga konstan menurut lapangan usaha 2008-2012 (juta rupiah). Jawa Timur: Badan Pusat Statistik.

Certo, S. C. (2000). Supervision: Concepts and skill building. $3^{\text {rd }}$ Edition. New York: McGraw-Hill.

Cooper, D. R., \& Schindler, P. S. (2008). Business research methods. $10^{\text {th }}$ Edition. Singapore: McGraw-Hill International Edition.

Desa, M. S. (2008). Pengaruh sosiodemografi dan karakteristik pekerjaan terhadap keinginan pindah kerja pada bidan di Kabupaten Serdang. Unpublished undergraduate thesis, Sumatera Utara University, Sumatera Utara Indonesia.

Etnaningtiyas, A. P. (2011, Oktober). Faktor-faktor yang mempengaruhi intensi turnover pada pekerja PT Alenatex Bandung. Unpublished undergraduate thesis, Syarif Hidayatullah University, Jakarta Indonesia.

Ghozali, I. (2005). Analisis Multivariate. Semarang: Badan Penerbit Universitas Diponegoro.

Gomes, F. C. (2003). Manajemen sumber daya manusia. Yogyakarta: Andi.

Heinen, M. M., Achterberg, T. V., Schwendimann, R., Zander, B., Matthewsd, A., Kozka, M., Ensio, A., Sjetne, I. S., Casbas, T. M., Ball, J., \& Schoonhoven, L. (2012). Nurses' intention to leave their profession: A cross sectional observational study in 10 European countries. International Journal of Nursing Studies 50, 174-184.

Hellriegel, D., \& Slocum, J. W. (2011). Organizational behavior. $13^{\text {th }}$ Edition. Mason: South-Western Cancage Learning.

Ivancevich, J. M., Konopaske, R., \& Matteson, M. T. (2012). Organizational behavior and management. $10^{\text {th }}$ Edition. NY: McGraw-Hill//rwin.

Kast, F. E. (1990). Organisasi dan manajemen. Jakarta: PT Bumi Aksara.

Mangkunegara, A. P. (2013). Manajemen sumber daya manusia perusahaan. Edisi 11. Bandung: PT Remaja Rosdakarya.

Mobley, W. H. (1986). Pergantian pekerja: Sebab, akibat dan pengendaliannya. Jakarta: PT Pustaka Binaman Pressindo.

Nayaputera, Y. (2011). Analisis pengaruh kepuasan kerja dan stres kerja terhadap intensi turnover 
customer service employee di PT Plaza Indonesia Realty tbk. Unpublished undergraduate thesis, Indonesia University, Jakarta Indonesia.

Novliadi, F. (2007). Intensi turnover pekerja ditinjau dari budaya perusahaan dan kepuasan kerja. USU Institutional Repository, 1-34.

Peterson, J., Hall, L. M., Pallas, L. O., \& Cockerill, R. (2011). Job satisfaction and intentions to leave of new nurses. Journal of Research in Nursing 16, 536-548.

Robbins, S. P. \& Judge, T. A. (2013). Organizational behavior. $15^{\text {th }}$ ed. USA: Prenctice Hall Inc.
Sugiyono. (2010). Metode penelitian bisnis: pendekatan kuantitatif, kualitatif dan $R \& D$. Edisi 15. Bandung: Alfabeta.

Sutanto, E. M. \& Gunawan, C. (2013). Kepuasan kerja, komitmen organisasional dan turnover intentions. Jurnal Mitra Ekonomi dan Manajemen Bisnis, 4(1), 76-88.

Sutapa. (2003). Pengaruh kepuasan kerja dan komitmen organisasional terhadap keinginan berpindah auditor (studi kasus pada KAP Jawa Tengah). Jurnal Ekobis, 4(2). 